CORRECTION

\title{
Correction: Enlightened: addressing circadian and seasonal changes in photoperiod in animal models of bipolar disorder
}

Richard McCarty (D), Travis Josephs, Oleg Kovtun and Sandra J. Rosenthal (D)

(c) The Author(s) 2021

Translational Psychiatry (2021)11:400; https://doi.org/10.1038/s41398-021-01521-5

Correction to: Translational Psychiatry https://doi.org/10.1038/ s41398-021-01494-5, published online 05 July 2021

The original version of this article unfortunately contained a mistake in Table 1. All blank boxes $(\square)$ in Table 1 columns 3 and 4 should be replaced with the horizontal solid arrow $(\rightarrow)$. The remaining dashed horizontal arrow $(-->)$ in the bottom cell of column 3 of Table 1 should be replaced with the horizontal solid arrow $(\rightarrow)$ as well. We apologize for this error caused by the typesetter. The original article has been corrected.

\begin{abstract}
(c) (i)
Open Access This article is licensed under a Creative Commons Attribution 4.0 International License, which permits use, sharing, adaptation, distribution and reproduction in any medium or format, as long as you give appropriate credit to the original author(s) and the source, provide a link to the Creative Commons license, and indicate if changes were made. The images or other third party material in this article are included in the article's Creative Commons license, unless indicated otherwise in a credit line to the material. If material is not included in the article's Creative Commons license and your intended use is not permitted by statutory regulation or exceeds the permitted use, you will need to obtain permission directly from the copyright holder. To view a copy of this license, visit http://creativecommons. org/licenses/by/4.0/.
\end{abstract}

(c) The Author(s) 2021 